Millatī, Journal of Islamic Studies and Humanities

Vol. 5, No. 1, June 2020: p. 65-80. DOI: 10.18326/mlt.v5i1. 65-80

p-ISSN : 2541-3627 ; e-ISSN 2540-9964

Website: http://millati.iainsalatiga.ac.id/index.php/millati/index

\title{
Tilawah of the Quran in Anna M. Gade's View : Philosophical Studies and Its Relevance to the Quranic Sciences
}

\author{
M. Zia Al-Ayyubi \\ Universitas Islam Negeri Sunan Kalijaga Yogyakarta \\ ziamubammad15@gmail.com
}

\begin{abstract}
This paper is a review of the thoughts of a Western scholar named Anna M. Gade about qira'ah and tilawah. Anna M. Gade is a professor in the field of Environmental Studies at the University of Wisconsin, Madison, United States. Using a philosophical approach, this study aims to explain how the thoughts of Anna M. Gade is related to tilawab al-Quran. One of his works shows specifically under the title "the Quran Recitation", which means tilawah al-Quran. When it is called tilawah quran (reciting Quran), of course, there is a connection with qira 'ah alQuran which equally shows the meaning of the reciting of the Quran. For this problem, Gade explained that tilawah is a part of qira'ah, because the scope of qira'ah is more common than tilawah. In addition, Gade also explained tilawah on the side of the Quran description of tilawah, tilawah as a practice of praying, beauty, to the competition of tilawah Quran.
\end{abstract}

Keywords: Tilawah, Quran, Anna M. Gade, 'ulum al-Quran

\begin{abstract}
Tulisan ini merupakan ulasan pemikiran salah seorang sarjanawan Barat yang bernama Anna M. Gade tentang tilawah. Anna M. Gade sendiri merupakan seorang profesor pada bidang Studi Lingkungan di Universitas Wisconsin, Madison, Amerika Serikat. Dalam salah satu karyanya, ia spesifik menunjukkan dalam judulnya "The Quran Recitation", yang berarti tilawah al-Quran. Ketika disebut tilawah al-Quran (bacaan al-Quran), tentu ini terdapat keterkaitan dengan qira'ah al-Quran yang secara bahasa sama-sama menunjukkan arti bacaan al-Quran. Untuk permasalah tersebut, Gade menjelaskan bahwa tilawah merupakan salah satu bagian dari qira'ah, karena cakupan dari qira'ahyang lebih umum dari pada tilawah. Selain itu, Gade juga menjelaskan tilawah pada sisi pendeskripsian al-Quran terhadap tilawah, praktik, keindahan, hingga kompetisi tilawah al-Quran.
\end{abstract}

Kata kunci: Tilawah, al-Quran, Anna M. Gade, 'ulum al-Quran

\section{INTRODUCTION}

The book of Quran is kalamullah that was revealed since fourteen centuries ago for His Messenger. The span of fourteen centuries ago and today is surely going through a series of extremely long life journeys. Although in a long time, learning the Quran still exists with its existence that is not done by places and times. Quran learning begins since the revelation of the Quran was first revealed, that is when the Prophet Muhammad received the revelation of 
Millatī, Journal of Islamic Studies and Humanities, Vol. 5, No. 1, June 2020: 65-80

Surah Al-Alaq: 1-5. In the revelation, the prophet was given a revelation in the form of a command to read.

Quranic learning begins with the angel Gabriel by way of talaqqi, which is to read the revelations by imitating what is conveyed by the angel Gabriel. Starting from learning this talaqqi model, then recitation of the Quran automatically arises. The reciting of this holy revelation is then termed by tilawah. The term of tilawah itself is certainly not a strange thing for Muslims. This term is often heard and appears especially for those who are or have studied the Quran.

Anna M. Gade is one of the reviewers of how exactly the explanation of the tilawah. In one of his works, he specifically shows in his book entitled Quran Recitation, which means reciting the Quran. The work is the result of research in Indonesia related to tilawah. He departed from the literature that talks about tilawah which he then described and studied in the living Quran. In one of his discussions, he discussed tilawah and qira'ah. When there is mention of tilawab al-Quran (reciting the Quran), of course, there is a connection with qira'ab al-Quran which equally shows the meaning of reciting the Quran.

So in this paper, using a philosophical approach, the author tries to examine how Anna M. Gade's view is related to tilawah, which of course is interesting to study by looking at Gade's background as the writer will explain in this paper. Furthermore, the results of his thought will be relevant to the Quranic sciences.

\section{DISCUSSION}

\section{Anna M. Gade's Academic Background}

Anna M. Gade was a Muslim scholar whose recent teaching and research discuss the global environment with a humanistic perspective. Gade was a Southeast Asian person, in the sense that he has lived there for a long time to conduct his field research in that area (Indonesia, Malaysia, and Cambodia) for two decades. ${ }^{1}$

Anna M. Gade was a professor with many achievements who focus her studies on environmental studies at the Nelson Institute, University of Wisconsin, Madison, United States. He obtained his M.A. and Ph.D. at the University of Chicago in the History of

1 Lehigh University, Anna M. Gade, https://cgis.cas2.lehigh.edu/content/anna-m-gade, accessed on November 26th, 2019. 
Religions, with Islam as his scientific specialization. In addition, he also earned a B.A. in Mathematics from Swarthmore University. He has also held academic positions at Cornell University (Eastern World Studies), Princeton University (Music and Religious Studies), Oberlin University (Religious Studies), Victoria University, Wellington, New Zealand (Religious Studies), and in Asian Languages and Cultures in the University of Wisconsin, Madison (Asian Language and Culture Studies). In addition, he also teaches courses in Environmental Humanities, Islamic Studies, and Religious Studies. ${ }^{2}$

At the University of Wisconsin, Madison, Gade works at the Faculties affiliated with the Center for Culture, History, and Environment, the Center for Southeast Asian Studies, the Department of Asian Languages and Cultures, the Study of Religion, and the Human Rights Program at the Center for Global Legal Studies at the University of Wisconsin. Most recently, he served as Chairman of the American Academy of Religion and has written two books dedicated to understanding the Quran that is in Arabic-language with various Muslim perspectives entire the world. His latest book was entitled Muslim Environmentalists: Religious and Social Foundations, which was published by Columbia University Press in August 2019. ${ }^{3}$ In addition, he was recorded as the lecturer at the Gadjah Mada University in Yogyakarta in 2011 about Islam and the environment. ${ }^{4}$

Initially, Anna M. Gade's published work earlier emphasized the theory and methods in religious studies and Islamic studies. His research began in 2007 that explains the global culture, history, and religion towards environmental change, with a specialization in the study of history, knowledge, and practice in Southeast Asia. This and previous projects are based on his fieldwork in Indonesia and elsewhere in the immediate region, such as Cambodia and Malaysia. Aside from being a researcher, Gade also actively teaches lectures in the fields of Islamic studies, global religious studies, Asian studies, and environmental ethics studies and

\footnotetext{
University of Wisconsin, Anna M. Gade, Professor, https://sites.google. com/a/wisc.edu/amgade/accessed on November 26th, 2019.

${ }^{3}$ University of Wisconsin, Anna M. Gade, Professor.

${ }^{4}$ Center for Religious and Cross-cultural Studies UGM, Dr. Anna M. Gade (University of Wisconsin Madison, accessed on December 3th 2019.
} 
Millatī, Journal of Islamic Studies and Humanities, Vol. 5, No. 1, June 2020: 65-80

environmental studies using a humanistic perspective. He has also completed the text of a book entitled Environmentalism and Environmental Humanities. ${ }^{5}$

Some of Anna M. Gade's works that have been published both printed and networked publications in the form of books and articles are as follows; ${ }^{6}$ 1) Muslim Environmentalisms: Religious and Social Foundations (2019); 2) The Quran: An Introduction (2010); 3)Perfection Makes Practice: Learning, Emotion, and the Recited Quran in Indonesia (2004); 4) "Smoke, Fire, and Rain in Muslim Southeast Asia: Environmental Ethics in the Time of Burning" (2018), in Piety, Politics, and Everyday Ethics in Southeast Asian Islam; 5) "Beyond "Hope: Religion and Environmental Sentiment in the USA and Indonesia" (2018), in Feeling Religion; 6) "Emotion: Feeling "The Consolation" (2015), in Key Terms in Material Religion; 7) "Religious Biography of the Prophet Muhammad in twenty-first-century Indonesia" (2010), in The Cambridge Companion to Muhammad; 8) "Introduction" (2009), in The Crescent Moon: The Asian Face of Islam in New Zealand; 9) "Islam" (2008), in The Oxford Handbook of Religion and Emotion; 10) "Sunan Ampel of the Javanese Wali Songo" (2009), in Tales of God's Friends: Islamic Hagiography in Translation; and 11)“Quran Recitation” (2006), in The Blackwell Companion to the Quran.

As explained above, it can be seen that Anna M. Gade is a person who focuses her studies in the field of research, especially field research on Islamic studies in certain areas. By looking at his works, it can be said that Anna M. Gade is someone who deals with living Quran studies because many in his field-based on research studies. This is interesting to study more deeply related to Anna M. Gade's views on tilawah.

\section{A Discourse About Qira'at and Tilawah}

Terminologically, qira'at (قراءات) is a plural form of the word qira'ah (قراءة) that is a mashdar form of the word qara'a-yaqra'u (يقرأ-قرأ). The meaning of qira'abis reciting. As for the terminology, al-Zarqani explains the meaning of the term qira'at in terms as a school adhered to by a priest of the qurra' experts' who differs from the others in the

\footnotetext{
5 Center For South Asia, Anna M. Gade, https://southasia.wisc.edu/staff/gade-anna-m/, accessed on November 26th, 2019.

${ }^{6}$ University of Wisconsin, Books \& Book Chapters, Anna M. Gade, https://sites.google.com/a/wisc.edu/ amgade/books, accessed on December 3th 2019.
} 
pronunciation of the Quran with appropriateness history and how to read from it, both the differences in pronunciation of the letters or pronunciation of the form. ${ }^{7}$

Understanding in the terms also expressed by Ibnul Jazar as quoted by the Shaykh Muhammad Ismail, namely the science of how to read the Quran words, and different ways to read it according to the versions of the people who quoted it. $^{8}$ Whereas Abduh Zulfidar Akaha offers the definition of qira'at in terms as the science that studies about the procedures for conveying or reciting a Quranic sentences and its differences that are based on those who quote them.

When the qira'at rests on its relationship to the Quran then what needs to be paid attention to is that they both have a close relationship, that is the relationship between the parts of valid qira'at are a part of the Quran itself. Both are not two different or completely different things. Neither are the two things essentially one, but between the two there is a very close attachment or relationship. ${ }^{10}$

Judging from the types of qira'at in terms of sanad (transmission), al-Suyuthi in his book al-Itqan fi' Ulum al-Quran, dividing it into six, namely mutawattir, masybur, ahad, dan syaz, maudu', mudraj. ${ }^{11}$ While qira'at seen from the number is divided into three, namely qira'at al-sab' (resting their reciting on the famous qurra' priest numbering seven, namely Nafi', Ibn Kathir, Abu Amru, Ibn Amir, Ashir, Hamzah, al-Kisa'i), qira'at' al-ashrah (ie qira'a $t s^{\prime} b^{\prime} a b$ plus three qira'at based on Abu Ja'far, Ya'qub, Khalaf al-'Asyir), and qira'at arba' 'ashrah (ie qira'at 'ashrah plus four qira'at that are based on Ibn Muhaishin, al-Yazadi, Hasan al-Basri, and al-A'masy). Of the three qira'at, qira'at al-sab' is the most famous, then followed by qira'at" al-ashrah. ${ }^{12}$

In its development, qira'at cannot be separated from talaqqi, the meaning of which is taken as the taking of the Quran when during the time of the Prophet up to now is through narration and talaqqi from the people who are tsiqab and can be trusted. Talaqqi

7 Muhammad 'Abdul 'Adzim Al-Zarqani, Manahil Al-Irfan, Vol. 1 (Beirut: Dar Al-Kitab Al-'Ilmiyah, 1996), p. 410.

8 Sya'ban Muhammad Ismail, Mengenal Qira'at Al-Quran (Semarang: Dimas, 1993), p. 24.

${ }_{9}$ Abduh Zulfidar Akaha, Al Qur'an dan Qiroat (Jakarta: Pustaka Al-Kautsar, 1996), p.118.

${ }^{10}$ Sya'ban Muhammad Ismail, Mengenal Qira'at Al-Quran..., p. 25-26. ttp), p. 77.

11 Abdurrahman ibn Al-Kamal Al-Suyuthi, Al-Itqan fi 'Ulum Al-Quran, Vol. 1 (Beirut: Dar Al-Fikr, 12 Abduh Zulfidar Akaha, Al Qur'an dan Qiroat ...., p. 128-129. 
Millatī, Journal of Islamic Studies and Humanities, Vol. 5, No. 1, June 2020: 65-80

and the narration are the main keys in reciting the Quran correctly and precisely as taught by the Prophet to his companions. ${ }^{13}$

Etymologically, the word tilawah is a mashdar form of the word tala-yatlu-tilawah (تلا - تلاوة)

which means to read or to study. ${ }^{14}$ In addition, in the Al-Munawwir dictionary, the word tilawah (التلاوة) is the same as qira'ah (القراءة) which means reciting. ${ }^{15}$ Likewise in the Contemporary Arabic-Indonesian dictionary, tala means reciting, while the form of mashdar (تلاوة) has a meaning of reciting or recitations. Tilawah itself according to the Big Indonesian

Dictionary means the reciting (verse of the Quran) well and beautifully. ${ }^{16}$ From all of the understanding in dictionaries above, it can be concluded that tilawah is a word derived from Arabic that is then absorbed into one of the words (recitations) in Indonesian which means reciting or reciting the Holy Quran.

The word utlu (أتل) is taken from the word tilawab that originally had the meaning of following. A person who reads is a person whose heart or tongue follows what is counted from the symbols of reciting, letter by letter, part by part of what he reads. For example, someone says "aba ", then to read, people must see and pay attention to the three the letters and follow one after another, so that was born reciting "aba". ${ }^{17}$

The word tilawah is a word that recorded in the Quran verses of al-Baqarah: 121 as follows:

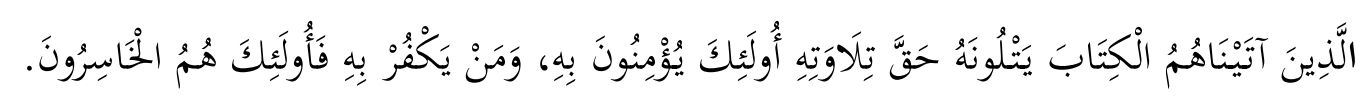

Those whom We gave the Book to, they read it with real reciting, they believe in it. And whoever denies him, they are the losers.

${ }^{13}$ Abduh Zulfidar Akaha, Al Qur'an dan Qiroat ...., p. 129.

${ }^{14}$ Mahmud Yunus, Kamus Arab Indonesia (Jakarta: Yayasan Penyelenggara Penterjemah/Pentafsir AlQuran, 1973), p.79.

${ }^{15}$ Ahmad Warson Munawwir, Al-Munawnir Kamus Arab-Indonesia (Surabaya: Pustaka Progresif, 1997), p. 138.

${ }^{16}$ Departemen Pendidikan Nasional, Kamus Besar bahasa Indonesia (Jakarta: Gramedia Pustaka Utama, 2008), p. 935.

${ }^{17}$ Iskandar Dzulqarnain, "Implikasi Tilawah Al Quran terhadap Ketenangan Hati Perspektif Tafsir AlMishbah”, Thesis (Surabaya: Pascasarjana UIN Sunan Ampel, 2018), p. 31. 
Ibnu Katsir explains the word haqqa tilawatih (حَقَّ تِلَاوَتِّهِ) in his work of Tafsir ibn alKatsir is to justify what has been permitted by Allah, and forbid what has been forbidden by Allah, to read the Quran as has been revealed by Allah, and not to change the sentence of words (tashrif) from its place, and not mentoring it from something other than what it should be. $^{18}$

There is another explanation given by Nashir al-Din Abu Sa'id in his tafsir, Tafsir alBaidlawi, about what was meant by nَيتْلُونَهُ حَقَّ تِكِاوَتِِهِ namely to consider or pay attention to the pronunciation of the text so that it does not change the letter (tashrif), and contemplating the meaning contained, and practice what he set. ${ }^{19}$

As for tilawwah according to terms as revealed by Ziad Khaled Moh al-Daghamen, it is said that tilawah means to follow the instructions and the rules of scriptures. This means an ongoing necessity in understanding the meaning and truths (baqaiq) of the Quran in the heart. In contrast to tilawwah that is more devoted to the Quran alone. According to Abu Hilal al'Askari, quoted from Ar-Raghib al-Asfahani in al-Furq al-Lughawiyah and Murtadha al-Zubaidi in Taj al-'Ursy, states that tilawah is devoted to following the kitabullab by reciting (qira'ab) and obeying (irtisam) its contents, whether in the form of commands, prohibitions, motivations or threats. Thus, it can be said that tilawah is more specific than qira'ah. Every tilawwah is qira'ah, but not every qira'abis tilāwah. ${ }^{20}$

Tilawah in terms of Zainuddin also described as the activity of reciting, understanding, pondering, and living the verses and its meanings, as well as the content of the verses contained in the word of God ( Quran) which was revealed to the Prophet Muhammad PBUH., at the same time serves as a guide, a lesson for those who believe in it, as well as valuable worship for those who read it by looking at the Mushaf, by involving oral, hearing, mind and heart. ${ }^{21}$

\footnotetext{
18 Abu Al-Fida Ibn Katsir, Tafsir ibn Katsir, Vol. 1 (Beirut: Dar Ahya’ al-Turas \al-'Arabi, 1985), p. 393.

${ }^{19}$ Nashir Al-Din Abu Sacid, Tafsir Al-Baidlawi, Vol. 2 (Beirut: Dar Al-Fikr, 1996), p. 95.

${ }^{20}$ Usup Romli, and Saepul Anwar, "Konsep Taklim dalam Alquran”, Jurnal Pendidikan Agama Islam Ta'lim, 11, No. 1 (2013); p. 18.

21 Zainuddin, “Tilawah Al-Quran: Implikasinya terhadap Kesehatan Mental”, Thesis, (Jakarta: Fakultas Psikologi Universitas Islam Negeri Syarif Hidayatullah, 2007), 18.
} 
Millatī, Journal of Islamic Studies and Humanities, Vol. 5, No. 1, June 2020: 65-80

The Quran itself distinguishes the use of the word tilawah with the word qira'ah, which initially contains the same meaning. The word tilawah in its various forms, if what is meant is reciting (because there is another meaning to this word) then the object of reciting is something that is great and sacred or true. As for qira, the object is more general, including the sacred or impure, the content can be positive or negative. That why al-Baqarah verse 121st uses the word $u t l u$, because the object is a revelation. While the command to read in the first revelation is iqra', where the object can cover all kinds of reciting, including the revelations of other God. It could be the word utlu which literally means following the texts chosen because they are sacred or true, also to indicate that what is read should be followed by practice. ${ }^{22}$

From a general perspective and views according to some of the figures above, then this needs to be taken into consideration and compared for the next analysis process. Therefore, it is necessary to explain how Anna M. Gade's view of tilawah itself.

\section{Tilawah in Anna M. Gade's View}

There is a link between the terms of Qira'ah and tilawah. Gade explained Qira'ah as the sciences of the reciting of the Quran, the knowledge of reciting the Quran. As for the relation to tilawah, he explained that tilawah (recitation of the Quran) is part of the fundamental branches of study and learning of the Quran. Thus, it can be said that tilawah is one of the fields or parts of the science of qira'at al-Quran. The term tilawah often appears in the Quran in the form of nouns and verbs. Usually, when the word refers to reciting the Quran the word recitation means to follow the message of the Quran by sounding the sound. ${ }^{23}$

Quran it self describes some general descriptions related to tilawah. Besides that, there are also a few explanations that are specific to the technique or practice. This is a uniqueness that exists in the Islamic teaching system in which the Quran has the most authoritative role to be used as a guide for thoughts and actions for those who believe it,

${ }^{22}$ Quraish Shihab, Tasir Al-Mishbah: Pesan, Kesan dan Keserasian Al-Quran, Vol. 1 (Jakarta: Lentera Hati, 2002), p. 29.

23 Anna M. Gade, "Qur'an Recitation", The Blackwell Companion to the Qur'an, (Malden: Blackwell Publishing, 2006), p. 483. 
it can be said that this is a function of tilawah al-Quran for its readers (who believe in the Quran). ${ }^{24}$

Gade explained that the verses of the Quran that describe tilawah are; First, the order specifically addressed to the Prophet Muhammad PBUH., and generally addressed to Muslims to read the Quran (to make a sound or sound). The order was recorded in the revelation which was first revealed to the Prophet Muhammad, namely in the first and second verses of alAlaq. ${ }^{25}$ Secondly, the Quran explains the guidelines on how to read it as explained in the Qs. alMuzammil: $4 .^{26}$ Gade explained that what is meant by tartil here is to be careful and not in a hurry. Third, the instructions in reciting the Quran as recorded in Qs. al-Qiyamah: 16-18. ${ }^{27}$ Gade continued, Quran actually contains many suggestions relating to tilawah al-Quran, such as reciting it with full concentration at night as a deed of worship as well as to remember (memorize) and maintain the revelation of the Quran. ${ }^{28}$

In addition to describing the description of tilawah in the Quran, Gade also describes the effect or impact of the reciting (tilawah) Quran that is felt for people who read or listen to it. First, as explained in Qs. al-Zumar: $23^{29}$ that the Quran describes the reaction caused in the form of shivering and trembling feelings for its readers. Second, crying in recognition of the truth of the message of the Quran when it is read as recorded in Qs. al-Ma'idah: $83 .{ }^{30}$ Third, the description of the Quran that connects the response of feelings with the moral state of people who believe in the revelation as recorded in Qs. al-Isra' verses 107-109. ${ }^{31}$

Gade's description of tilawah which refers to the Quran shows that tilawah is one of the things discussed in the Quran. Starting from the command, how to read, etiquette, direction, advice, to the impact of the tilawah. The description of tilawah in the Quran, as explained by Gade, is a descriptive-theoretical study. Because tilawah is an action that must be practiced.

\footnotetext{
${ }^{24}$ Anna M. Gade, “Qur'an Recitation”..., p. 482.

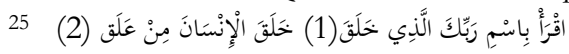

26 تَ....

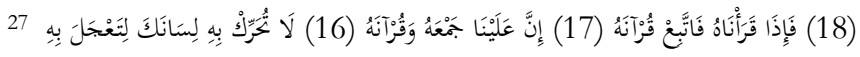

28 Anna M. Gade, “Qur'an Recitation”..., p. 482.

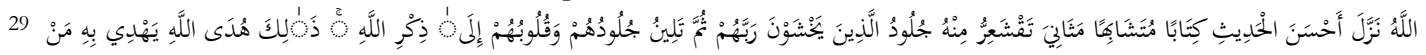

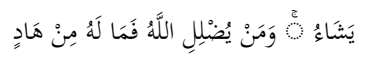

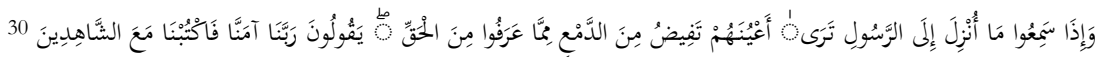

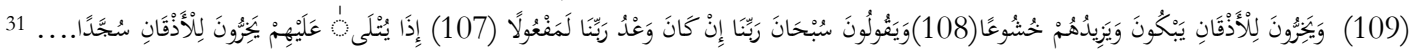


Millatī, Journal of Islamic Studies and Humanities, Vol. 5, No. 1, June 2020: 65-80

Therefore this study does not stop only in the area of the text (Quran), but then Gade goes on to explain how this principle is practiced in daily life.

\section{Tilawah Practices as Worship, Different Ways, Beauty, to Competition}

The practice of reciting the Quran is a fundamental part of Islamic education, practice, and obedience. During the holy month of Ramadan, the Quran is read in a nightly service which is commonly called the tara $>$ wih prayer. In reciting the tarawih prayer, usually, the Quran which amounts to 30 juz is divided every day one juz, read sequentially (the first day of juz 1 , the second day of juz 2, and so on), so that the reciting of the Quran ' can be completed (khatam) in one month. In fact, during the month of Ramadan as well as during the pilgrimage season, the entire Quran can be read and recited in one night by every devout Muslim. ${ }^{32}$

Gade added, other practices in reciting the Quran are also needed as part of a series of worship in Islam, as in the prayer. In practice, reciting al-Fatihah at least seventeen times a day by every Muslim during prayer. This is because reciting the Surah al-Fatihah is one of the pillars of prayer in every raka'at. Besides al-Fatihah, in prayer, it is also advisable to read other letters after reciting al-Fatihah, especially in the first raka'ah and second raka'ah. The reciting of what letter to read depends on each individual (if the prayer is munfarid) and depends on the imam (if the congregational prayer). However, in practice, the recitation of the letters chosen after al-Fatihah are short letters contained in part of juz 30. Not only prayer, but the practice of reciting the Quran can also be used as a medium of remembrance (zikr) of Allah. This is usually done by Sufis who practice ziker by using verses in which there is al-asma'al-husna. ${ }^{33}$

Gade explained that in the practice of reciting the Quran there are different ways or styles depending on the reader. This difference can be identified, i.e. lies in the difference in reciting speed. He explained that there were at least two styles of reciting, namely reciting in hadr or in tartil. What is meant by hadr is a quick reciting, usually done because what has been read has been recorded in the reader's brain memory. Recitation of the Quran in the prayers according to Gade also tends to be quite fast when reciting it. While tartil or murattal can also be called a slower reciting, usually used for learning and tadarrus. There is also material that

32 Anna M. Gade, “Qur'an Recitation”..., p. 486.

33 Anna M. Gade, “Qur'an Recitation”..., p. 487. 
needs attention in reciting the Quran, which is an etiquette when reciting or listening to it. Gade explained that etiquette that needed attention was silent and respectful when listening to the chanting of the Quran, sitting facing to the Qibla (if possible) when reciting it, repeating the reciting of verses, reciting ta'awuz and basmalah at the beginning, and ending with recite shadaqallah al-'azim, stop to answer the greetings when there are people who say greetings, stop when they hear the call to prayer, perform prostrations while after listening to or reciting verses of sajdah. ${ }^{34}$

The practice of reciting the Quran is also inseparable from the aesthetics of recitation. Gade termed this as the Quranic Esthetic. The assumption is that the teachings, worship, and aesthetics are closely related to the theory and practice of reciting the Quran. This connection is an important part because reciting the Quran is to be able to understand the true voice of God (Kalam Allah). ${ }^{35}$

In the early Islamic tradition, the rhythm used for reciting the Quran was not clearly known, because it was not recorded in history. The tradition of the practice of reciting the Quran with this rhythm began to be recorded in history since the Abbasid Dynasty. The practice of reciting with this rhythm then develops using tartil (mujawwad) style. At the same time, the readers of the Quran began to formulate a song system (maqam, plural maqamat) reciting in a mujawwad style. Furthermore, with this song a discourse appears in the literature about reciting the Quran in a tone, called Gade, qira'abbi al-labn. The rhythm structure used at that time was the art of music originating from Arabic. ${ }^{36}$

The development of recitation using rhythm does not stop at the recitation system of the Quran which takes into account its aesthetic aspects. In its development, the recitation of the Quran in rhythm was then used as a competition. In this case, Gade explained by conducting a study first, namely more precisely research in Indonesia.

This reciting competition with the rhythm of the Quran is usually called the Musabaqah Tilawatil Quran (MTQ). According to historical records, MTQ has existed in Indonesia since the 1940s, namely since the founding of Jami'iyyatul Qurro 'wa al-Huffadz (JQH) which was founded by Nahdlatul Ulama (NU). Since 1968, when the Minister of

\footnotetext{
34 Anna M. Gade, “Qur'an Recitation”.....p. 487.

35 Anna M. Gade, “Qur'an Recitation”..., p. 489.

36 Anna M. Gade, “Qur'an Recitation”..., p. 490.
} 
Millatī, Journal of Islamic Studies and Humanities, Vol. 5, No. 1, June 2020: 65-80

Religion of the Republic of Indonesia was held by K.H. Muhammad Dahlan, MTQ was institutionalized nationally. The national MTQ was first held in Makassar in the month of Ramadan in 1968. At that time the MTQ only competed in the adult branch. Whereas the second MTQ was held in Banjarmasin in 1969, and the third in 1970 in Jakarta. ${ }^{37}$

In the Quran reciting contest in Indonesia, Gade explained that the Quran was also interpreted in Indonesia as a form of da'wah. The increasing popularity of tilawah Quran in Indonesia and the competition of tilawah contributed to an explosion of interest, new media, and techniques in the study and appreciation of tilawah al-Quran in Southeast Asia. In addition, the presence of recitations also has a positive effect on Muslim youth. This MTQ is held and handled by many people in Indonesia. Gade continued, with phenomena that occur like this, MTQ functions as one way to propagate Islam. It also functions as a means to express Islam that is unique to Indonesia. As for what is meant by the competition which is used as the symbol of Islam is understood as a form of learning and preaching with behavior (bi al-hal) aimed at Muslims. This competition can show how the reciting of the Quran which in practice is a form of worship, but also has a function to restore the rise of Islam in the world today. ${ }^{38}$

Gade's explanation above can be simplified that tilawah is one of a series that cannot be separated from worship. Tilawah in practice there are different ways to read it depending on the conditions and who reads it. Tilawah cannot be separated from beauty because what is read is not ordinary text, but it is a holy book spoken by God. Tilawah can also be practiced as a competition for the purpose of learning the Quran that is good, beautiful, and true and at the same time becomes a propaganda media to broadcast Islam.

\section{Tilawah and Its Relevance to the Quranic Sciences}

Discussing the Quranic sciences ('ulum al-Quran), so the concern here is about the interpretation of the Quran. To borrow the term as revealed by Muhammad Chirzin, that Quranic sciences are seen by interpreters as a science of interpreting the Quran. In Quranic sciences itself has scientific branches where scholars differ in their opinions.

\footnotetext{
${ }^{37}$ Nur Rohman, “Anna M. Gade dan MTQ di Indonesia: Sebuah Kajian Metodologis”, Jurnal Al-A'raf 13, No. 1 (2016); p. 114.

38 M. Gade, “Qur'an Recitation”..., p. 492.
} 
While Muhammad Chirzin divided it into 26 branches. ${ }^{39}$ As according to Abdul Jalil, in general, the branches of Quranic sciences are divided into five major themes; first, the sciences relating to the descent of the Quran, such as the discussion of nuzul al-quran or how the Quran descended. Second, the sciences relating to the reciting of the Quran, in this case, is tilawah. Third, the sciences relating to the codification of the Quran, consisting of the collection of the Quran, the order of verses and letters, the number of verses and letters, and the knowledge of Rasam Mushaf. Fourth, the sciences of interpretation and takwil al-Quran. Fifth, the sciences relating to the peculiarities and miracles of the Quran. ${ }^{40}$

In addition there is a description of the branches of Quranic sciences offered by Hasbi Ash-Shiddieqy. He divided Quranic sciences by 17 branches, and one of them was 'ilm adab a-tilawah al-Quran, the science that discusses all the rules that must be used and implemented when reciting the Quran. ${ }^{41}$ Meanwhile, in the book al-Mababis fi ulum alQuran, al-Qatthan explains the discussion about tilawah including one of the branches of Quranic sciences (in the branch of al-qira'at wa al-qurra). Tilawab's discussion departs from the story of one of the qurra priests named Abdullah ibn Mas'ud, that he was someone who had a sweet and clever voice (good and right) in reciting the Quran. It was also explained by al-Qatthan that the scholars' past and present paid great attention regarding tilawah or how to read the Quran properly and correctly. Therefore, the scholars' formulate knowledge about reciting the Quran properly and correctly, which is commonly referred to as the science of recitation (tajwid). ${ }^{42}$ Thus, it can be said that tilawah and tajwid are two branches of science that have an attachment that cannot be separated from one another.

the explanation above shows that tilawah is one of the branches of Quranic sciences. As for the relation to tilawah presented by Anna M. Gade, he shows that there is complexity in one branch of the Quranic sciences, namely recitations. Starting from the

\footnotetext{
${ }^{39}$ Muhammad Chirzin, Al-Quran dan Ulumul Qur'an, (Jakarta: Dana Bhakti Prima Yasa, 1998), p. 1.

40 Abdul Jalil, Ulumul Quran Sebagai Dasar Berinteraksi dengan Alquran, 2019, http://aiat.or.id/ulumulquran-sebagai-dasar-berinteraksi-dengan-alquran, accessed on January 22th, 2020.

41 Wahyuddin dan M. Saifulloh, "Ulum Al-Quran, Sejarah dan Perkembangannya", Jurnal Sosial Humaniora 6, No.1 (2013); 24-25; Hasbi Ash-Shiddieqy, Sejarah dan Pengantar Ilmu Al-QuranTafsir, (Jakarta: Bulan Bintang, 1980).

${ }^{42}$ Manna' Khalil Al-Qatthan, Al-Mabahis fi 'Ulum Al-Quran, (Kairo: Maktabah Al-Wahbiyah, 2000), p. 177.
} 
Millatī, Journal of Islamic Studies and Humanities, Vol. 5, No. 1, June 2020: 65-80

data he got in his field research, he showed that tilawah is not a simple concept as just reciting the Quran as a holy book but also incarnated as a form of worship practices in different ways, beauty or aesthetics, even competition intended as a means of Islamic da'wah.

As for the connection with Quranic sciences, it can be said that Gade has no different or extreme thoughts from the ulama 'interpretations related to the discussion of tilawah. Even Gade can complete information that has not been discussed in Quranic sciences with the data he obtained in his living Quran research. Gade's contribution to the development of Quranic sciences ('ulum al-Quran) made an important contribution to the current Islamic scientific tradition.

\section{CONCLUSION}

Anna M. Gade is an Islamic scholar and professor who focus his studies on environmental studies at the Nelson Institute, University of Wisconsin, Madison, United States. Gade was a prolific person with a myriad of works. one of his works is a book called Quran Recitation which contains a discussion of tilawah al-Quran. The word tilawab al-Quran has a correspondence with qira'ah al-Quran that equally shows the meaning of the reciting of the Quran. However, for Gade, tilawah is one part of qira'abbecause the scope of qira'ahis far more common than tilawah. Gade added that tilawah on the description of the Quran is not limited to reciting in worship, but includes practice, beauty, and even competition tilawah al-Quran. As for the connection with Quranic sciences ('ulum al-Quran), Gade developed the basics of the Quran recitations chapter as formulated by the commentators. The data obtained by Gade contributes that the problem of recitations has become more complex in the direction of the practice. This is Gade's contribution to the current Islamic scientific tradition.

\section{REFERENCES}

Akaha, Abduh Zulfidar. Al-Quran dan Qiroat. Jakarta: Pustaka Al-Kautsar, 1996.

Ash-Shiddieqy, Hasbi. Sejarah dan Pengantar Ilmu Al-QuranTafsir. Jakarta: Bulan Bintang, 1980. 
Center for Religious and Cross-cultural Studies UGM. Dr. Anna M. Gade (University of Wisconsin-Madison), $\quad$ https://crcs.ugm.ac.id/staff/dr-anna-m-gade-university-ofwisconsin-madison/, accessed on December 3th, 2019.

Center For South Asia. Anna M. Gade, https://southasia.wisc.edu/staff/gade-anna-m/, accessed on November 26th, 2019.

Chirzin, Muhammad. Al-Quran dan Ulumul Qur'an. Jakarta: Dana Bhakti Prima Yasa, 1998.

Departemen Pendidikan Nasional. Kamus Besar Bahasa Indonesia. Jakarta: Gramedia Pustaka Utama, 2008.

Dzulqarnain, Iskandar. "Implikasi Tilawah Al Quran terhadap Ketenangan Hati Perspektif Tafsir Al-Mishbah”. Thesis. Surabaya: Pascasarjana UIN Sunan Ampel, 2018.

Gade, Anna M.. "Qur'an Recitation", in The Blackwell Companion to the Qur'an. Malden: Blackwell Publishing, 2006.

Ismail, Sya'ban Muhammad. Mengenal Qira'at Al-Quran. Semarang: Dimas, 1993.

Jalil, Abdul. "Ulumul Quran Sebagai Dasar Berinteraksi dengan Alquran”, 2019, http://aiat.or.id/ ulumul-quran-sebagai-dasar-berinteraksi-dengan-alquran, accessed on Januari 22th, 2020.

Katsir, Abu Al-Fida Ibn. Tafsir ibn Kasir. Beirut: Dar Ahya’al-Turas\al-'Arabi, 1985.

Lehigh University. Anna M. Gade. https://cgis.cas2.lehigh.edu/content/anna-m-gade, accessed on November 26th, 2019.

Munawwir, Ahmad Warson. Al-Munawwir Kamus Arab-Indonesia. Surabaya: Pustaka Progresif, 1997.

al-Qatthan, Manna' Khalil. Al-Mababis fi 'ulum al-Quran. Kairo: Maktabah Al-Wahbiyah, 2000.

Rohman, Nur. "Anna M. Gade dan MTQ di Indonesia: Sebuah Kajian Metodologis”, Jurnal Al-A'raf13, No. 1 (2016); 114.

Romli, Usup, dan Anwar, Saepul. "Konsep Taklim dalam Alquran”, Jurnal Pendidikan Agama Islam-Ta'lim 11. No. 1. (2013); 18. 
Millatī, Journal of Islamic Studies and Humanities, Vol. 5, No. 1, June 2020: 65-80

Sa'id, Nashir Al-Din Abu. Tafsir Al-Baidlawi. Beirut: Dar Al-Fikr, 1996.

Shihab, Quraish. Tasir Al-Mishbah: Pesan, Kesan dan Keserasian Al-Quran. Jakarta: Lentera Hati, 2002.

al-Suyuthi, Abdurrahman ibn Al-Kamal. Al-Itqan fi 'Ulum Al-Quran. Beirut: Dār Al-Fikr, ttp.

University of Wisconsin. Anna M. Gade: Professor, https://sites.google. com/a/wisc.edu/amgade/, accessed on November 26th, 2019.

........, Books \& Book Chapters, Anna M. Gade, https://sites.google.com/a/wisc.edu/ amgade/books, accessed on December 3th, 2019.

Wahyuddin dan Saifulloh, M. "Ulum Al-Quran, Sejarah dan Perkembangannya", Jurnal Sosial Humaniora 6. No.1 (2013); 24-25.

Yunus, Mahmud. Kamus Arab Indonesia. Jakarta: Yayasan Penyelenggara Penterjemah/Pentafsir Al-Quran, 1973.

Zainuddin. "Tilawah Al-Quran: Implikasinya terhadap Kesehatan Mental”. Skripsi. Jakarta: Fakultas Psikologi Universitas Islam Negeri Syarif Hidayatullah, 2007.

al-Zarqani, Muhammad 'Abdul 'Adzim. Manahil Al-'Irfan. Beirut: Dār Al-Kitab Al'Ilmiyah, 1996. 